\title{
The Darwin Awards: sex differences in idiotic behaviour
}

\author{
(C) (ब) $\Theta$ OPEN ACCESS
}

\author{
Ben Alexander Daniel Lendrem student ${ }^{1}$, Dennis William Lendrem project manager, Institute of \\ Cellular Medicine ${ }^{2}$, Andy Gray consultant orthopaedic trauma surgeon ${ }^{3}$, John Dudley Isaacs director, \\ Institute of Cellular Medicine ${ }^{2}$
}

${ }^{1}$ The King Edward VI School, Morpeth NE61 1DN, UK; ${ }^{2}$ Newcastle University, Newcastle NE2 4HH, UK; ${ }^{3}$ Major Trauma Centre, Royal Victoria Infirmary, Newcastle NE1 4LP

\begin{abstract}
Sex differences in risk seeking behaviour, emergency hospital admissions, and mortality are well documented. However, little is known about sex differences in idiotic risk taking behaviour. This paper reviews the data on winners of the Darwin Award over a 20 year period (1995-2014). Winners of the Darwin Award must eliminate themselves from the gene pool in such an idiotic manner that their action ensures one less idiot will survive. This paper reports a marked sex difference in Darwin Award winners: males are significantly more likely to receive the award than females $(\mathrm{P}<0.0001)$. We discuss some of the reasons for this difference.
\end{abstract}

\section{Introduction}

Sex differences in mortality and admissions to hospital emergency departments have been well documented, ${ }^{1-7}$ and hypotheses put forward to account for these differences. These studies confirm that males are more at risk than females. Males are more likely to be admitted to an emergency department after accidental injuries, more likely to be admitted with a sporting injury, and more likely to be in a road traffic collision with a higher mortality rate. ${ }^{18-15}$ Some of these differences may be attributable to cultural and socioeconomic factors: males may be more likely to engage in contact and high risk sports, and males may be more likely to be employed in higher risk occupations. However, sex differences in risk seeking behaviour have been reported from an early age, raising questions about the extent to which these behaviours can be attributed purely to social and cultural differences. ${ }^{10-12}$

However, there is a class of risk - the "idiotic" risk-that is qualitatively different from those associated with, say, contact sports or adventure pursuits such as parachuting. Idiotic risks are defined as senseless risks, where the apparent payoff is negligible or non-existent, and the outcome is often extremely negative and often final.
According to "male idiot theory" (MIT) many of the differences in risk seeking behaviour, emergency department admissions, and mortality may be explained by the observation that men are idiots and idiots do stupid things. ${ }^{16}$ There are anecdotal data supporting MIT, but to date there has been no systematic analysis of sex differences in idiotic risk taking behaviour. In this paper we present evidence in support of this hypothesis using data on idiotic behaviours demonstrated by winners of the Darwin Award. ${ }^{17-21}$

Winners of the Darwin Award must die in such an idiotic manner that "their action ensures the long-term survival of the species, by selectively allowing one less idiot to survive." ${ }^{20}$ The Darwin Awards Committee attempts to make a clear distinction between idiotic deaths and accidental deaths. For instance, Darwin Awards are unlikely to be awarded to individuals who shoot themselves in the head while demonstrating that a gun is unloaded. This occurs too often and is classed as an accident. In contrast, candidates shooting themselves in the head to demonstrate that a gun is loaded may be eligible for a Darwin Award-such as the man who shot himself in the head with a "spy pen" weapon to show his friend that it was real. ${ }^{18}$

To qualify, nominees must improve the gene pool by eliminating themselves from the human race using astonishingly stupid methods. Northcutt cites a number of worthy candidates. ${ }^{17-21}$ These include the thief attempting to purloin a steel hawser from a lift shaft, who unbolted the hawser while standing in the lift, which then plummeted to the ground, killing its occupant; the man stealing a ride home by hitching a shopping trolley to the back of a train, only to be dragged two miles to his death before the train was able to stop; and the terrorist who posted a letter bomb with insufficient postage stamps and who, on its return, unthinkingly opened his own letter. 


\section{Methods}

Data for the 20 year period from 1995 to 2014 were obtained from the Darwin Awards (http://darwinawards.com).

Nominations for a Darwin Award are evaluated according to five rigorous selection criteria: death, style, veracity, capability, and self selection. ${ }^{20}$

- The candidate must be eliminated from the gene pool

- The candidate must show an astounding misapplication of common sense

- The event must be verified

- The candidate must be capable of sound judgment

- The candidate must be the cause of his or her own demise.

The Darwin Awards are open to all ethnic groups, cultures, and socioeconomic groups.

We reviewed all Darwin Award nominations, noting the sex of the winner. Our analysis included only confirmed accounts verified by the Darwin Awards Committee. Urban legends and unverified accounts were excluded. Honourable

mentions - worthy examples of idiotic behaviour not resulting in elimination from the gene pool—were also excluded from the analysis. Examples include the man who slipped when using a belt sander as an auto-erotic device and lost a testicle. Repairing his scrotum with a staple gun, he was able to salvage his remaining testicle thus failing to eliminate himself completely from the gene pool. ${ }^{17-21}$

\section{Statistical analysis}

A $\chi^{2}$ test was performed comparing the observed distribution of male and female award winners with the expected numbers under the null hypothesis of no sex difference. For the statistical analysis, we excluded those awards shared by both sexes-usually couples. This meant that under the null hypothesis we assumed Darwin Awards were equally likely to be awarded to males and females according to their approximate distribution in the overall population (50:50). Statistical tests were performed using the SPSS statistical analysis system version 19.

\section{Results}

Of the 413 Darwin Award nominations, 332 were independently verified and confirmed by the Darwin Awards Committee. Of these, 14 were shared by male and female nominees-usually overly adventurous couples in compromising positions-leaving 318 valid cases for statistical testing. Of these 318 cases, 282 Darwin Awards were awarded to males and just 36 awards given to females. There is a marked sex difference in Darwin Award winners (see figure $\downarrow$ ). Males thus made up $88.7 \%$ of Darwin Award winners, and this sex difference is highly statistically significant $\left(\chi^{2}=190.30 ; \mathrm{P}<0.0001\right)$.

\section{Discussion}

This paper reports marked sex differences in the distribution of Darwin Award winners, with males much more likely to receive an award. This finding is entirely consistent with male idiot theory (MIT) ${ }^{1620}$ and supports the hypothesis that men are idiots and idiots do stupid things.

However, this study has limitations. One of the weaknesses is the retrospective nature of the data collection. One alternative explanation for the marked sex difference in Darwin Award winners is that there is some kind of selection bias. Women may be more likely to nominate men for a Darwin Award, or there may be some selection bias within the Darwin Awards Committee. In addition, there may be some kind of reporting bias. Idiotic male candidates may be more newsworthy than idiotic female Darwin Award candidates.

Despite these limitations there can be little doubt that Darwin Award winners seem to make little or no real assessment of the risk or attempt at risk management. They just do it anyway. In some cases, the intelligence of the award winner may be questioned. For example, the office workers watching a construction worker demolishing a car park in the adjacent lot must have wondered about the man's intelligence. After two days of office speculation-how does he plan to remove the final support to crash the car park down safely? - they discovered, on the third day, that he didn't have a plan. The concrete platform collapsed, crushing him to death and flattening his mini-excavator.

In addition, alcohol may play an important part in many of the events leading to a Darwin Award. It is conceivable that the sex difference is attributable to sociobehavioural differences in alcohol use. Anecdotal data support the hypothesis that alcohol makes men feel "bulletproof" after a few drinks, and it would be naïve to rule this out. For example, the three men who played a variation on Russian roulette alternately taking shots of alcohol and then stamping on an unexploded Cambodian land mine. (Spoiler alert: the mine eventually exploded, demolishing the bar and killing all three men.) Unfortunately the data on alcohol consumption are incomplete and do not permit testing for sex differences after adjustment for differences in alcohol consumption between the sexes.

While MIT provides a parsimonious explanation of differences in idiotic behaviour and may underlie sex differences in other risk seeking behaviours, it is puzzling that males are willing to take such unnecessary risks - simply as a rite of passage, in pursuit of male social esteem, or solely in exchange for "bragging rights." Northcutt invokes a group selectionist, "survival of the species" argument, with individuals selflessly removing themselves from the gene pool. We believe this view to be flawed, but we do think this phenomenon probably deserves an evolutionary explanation. Presumably, idiotic behaviour confers some, as yet unidentified, selective advantage on those who do not become its casualties. Until MIT gives us a full and satisfactory explanation of idiotic male behaviour, hospital emergency departments will continue to pick up the pieces, often literally.

We believe MIT deserves further investigation, and, with the festive season upon us, we intend to follow up with observational field studies and an experimental study-males and females, with and without alcohol—in a semi-naturalistic Christmas party setting.

We thank Wendy Northcutt and the Darwin Awards Committee for permission to use their data. BL thanks The King Edward VI School, Morpeth, for its support and declares that the study did not get in the way of homework.

Contributors: BADL conceived the study, designed the data collection tools, and cleaned and analysed the data. All authors were involved in interpreting the results and drafting and revising the paper.

\footnotetext{
Archer J. Sex differences in aggression in real-world settings: a meta-analytic review. Rev Gen Psychol 2004;8:291.

2 Galdas PM, Cheater F, Marshall P. Men and health help-seeking behaviour: literature review. J Adv Nurs 2005;49:616-23.

3 Fehr-Duda H, De Gennaro M, Schubert R. Gender, financial risk, and probability weights. Theor Decis 2006:60:283-313.

4 Harris CR, Jenkins M, Glaser D. Gender differences in risk assessment: why do women take fewer risks than men? Judgm Decis Mak 2006;1(1): p. 48-63.
} 
5 Eckel CC, Grossman PJ. Men, women and risk aversion: experimental evidence. In: Plott $\mathrm{CR}$, Smith VL, eds. Handbook of experimental economics results. Vol 1. North-Holland, 2008:1061-73.

6 Sapienza P, Zingales L, Maestripieri D. Gender differences in financial risk aversion and career choices are affected by testosterone. PNAS 2009;106:15268-73.

7 Eagly AH. Sex differences in social behavior: a social-role interpretation. Psychology Press, 2013.

8 DeHaven KE, Lintner DM. Athletic injuries: comparison by age, sport, and gender. Am J Sports Med 1986;14:218-24.

9 Giesbrecht N. Drinking and casualties: accidents, poisonings and violence in an international perspective. Routledge, 2003.

10 Ginsburg HJ, Miller SM. Sex differences in children's risk-taking behavior. Child Dev 1982;53:426-8.

11 Gratz RR. Accidental injury in childhood: a literature review on pediatric trauma. J Trauma Acute Care Surg 1979;19:551-5.

12 Rivara FP, Bergman AB, LoGerfo JP, Weiss NS. Epidemiology of childhood injuries: II. Sex differences in injury rates. Am J Dis Child 1982;136:502-6.

13 Scheidt PC, Harel Y, Trumble AC, Jones DH, Overpeck MD, Bijur PE. The epidemiology of nonfatal injuries among US children and youth. Am J Public Health 1995;85:932-8.

14 Singer BR, McLauchlan GJ, Robinson CM, Christie J. Epidemiology of fractures in 15 000 adults the influence of age and gender. J Bone Joint Surg Br 1998;80:243-8.
15 Slovic P. Risk-taking in children: age and sex differences. Child Dev 1966;37:169-76.

$16 \mathrm{McPherson} \mathrm{J}$. Women are from Venus, men are idiots. Andrews McMeel, 2011.

17 Northcutt W, Kelly CM. The Darwin Awards 4: intelligent design . Dutton, 2006.

18 Northcutt W. The Darwin Awards: countdown to extinction. Dutton, 2010.

19 Northcutt W. The Darwin Awards: next evolution - chlorinating the gene pool. Dutton, 2008

20 Northcutt W. The Darwin Awards: The official Darwin Awards: 180 bizarre true stories of how dumb humans have met their maker. Orion, 2004.

21 Northcutt W. The Darwin Awards II: unnatural selection. Dutton, 2001.

\section{Accepted: 07 November 2014}

\section{Cite this as: BMJ 2014;349:g7094}

This is an Open Access article distributed in accordance with the Creative Commons Attribution Non Commercial (CC BY-NC 4.0) license, which permits others to distribute, remix, adapt, build upon this work non-commercially, and license their derivative works on different terms, provided the original work is properly cited and the use is non-commercial. See: http://creativecommons.org/licenses/by-nc/4.0/. 


\section{Figure}

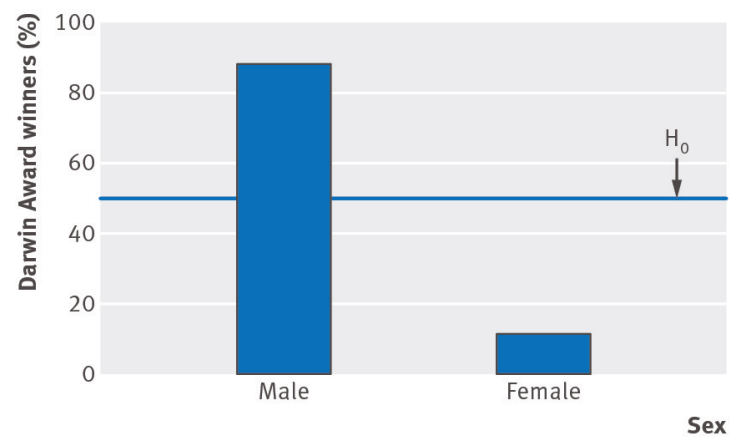

Male and female Darwin Award winners. Line $\mathrm{H}_{0}$ indicates expected percentages under the null hypothesis that males and females are equally idiotic 